\title{
THE INFLUENCE OF INVESTMENT KNOWLEDGE ON THE INTEREST OF STUDENTS INVESTING IN PEER TO PEER LENDING SHARIAH
}

\author{
Muhammad Doddy ${ }^{1}$, Zahrotul Millah²
}

${ }^{\text {l} S E B I ~ L e c t u r e r ~ \& ~ D o c t o r a l ~ C a n d i d a t e ~ A e U ~ M a l a y s i a ~ E m a i l: ~ m u h a m m a d . d o d d y @ s e b i . a c . i d ~}$ ${ }^{2}$ SEBI Email : milahmilahmil@gmail.com

\begin{abstract}
Peer to peer lending is an investment model that is developing in various countries, including Indonesia. This investment model has many advantages in terms of effectiveness so that it can make it easier for users to apply it. Moreover, peer to peer lending investment in Indonesia has a financing target for MSMEs so that this investment model can help finance in the microeconomic cycle. The convenience provided by the peer to peer lending investment model should be an attraction for people who are just starting investment such as students. Before investing, potential investors should have sufficient knowledge about investing in order to avoid the risk of failure that causes losses. This study aims to determine the effect of investment knowledge on the interests of STEI SEBI students investing peer to peer lending. The research method used is a quantitative mixture that is supported by qualitative data and data processed using SPSS ver. 23. The results of this study indicate that the T-test results of -0.200 and the significance value of 0.842. So it can be concluded that investment knowledge does not have a significant effect on students' interest in investing peer to peer lending. The results of the study are supported by data from interview results, which show that negative relationship results are not significant because one of them is theoretically not so influential if there is no its applicative science.
\end{abstract}

Keywords: Investment Knowledge, Peer to peer lending, Student Interest in Investing

\section{INTRODUCTION}

Investment is an essential part of economic development because to improve the economic condition of a country, it is necessary to have production supported by capital, and one of the sources of capital is an investment (Sodik \& Nuryadin, 2005). According to Sulistiawati, (2012) investment can affect labor absorption in Indonesia because of the production process that is supported by investment activities.

In general, all investment activities take place on the Indonesia Stock Exchange (BEI), which was established in 1991 and inaugurated by the Ministry of Finance in 1992. In the Indonesia Stock Exchange, many investment products are offered, such as stocks, bonds, sukuk, mutual funds, etc. In addition to the IDX, investment activities are also carried out by several financial institutions such as banks, cooperatives, fintech companies, and others. The investment organized by fintech companies is a newly developed innovation in Indonesia. The initial development of fintech in Indonesia has occurred since 2008 (OJK, 2017). 
Jurnal Ekonomi dan Perbankan Syariah

Vol. 7. No.2, 0ktober 2019: 20-33, ISSN (cet): 2355-1755 | ISSN (online): 2579-6437

\section{| 21}

The presence of technology should be able to be a tool for human life. In the current economic field, the fintech (financial technology) system is developing and becoming famous. Many innovations in finance have started to be based on technology. The peer to peer lending system is one of the financial innovations that are present in the middle of the technological era. Peer to peer lending system is a capital collection method that uses internet technology, and this system is a combination of crowdfunding with marketplace lending that brings together someone who has excess funds and someone who needs funds (Segal, 2015).

In Indonesia, a fintech company that uses a peer to peer lending system is generally a financing company for MSMEs, and fintech is an alternative for MSMEs to access funds other than the banking industry. The convenience provided by the peer to peer lending system decides business actors to make capital loans (Zeng et al., 2017). This makes the peer to peer lending company has many interested parties from the side of business actors who need capital loans.

Several weaknesses also accompany the ease of fintech in helping to increase financial inclusion. According to Muchlis (2018) the rapid development of fintech must be supported by the quality of technology in order to avoid inequality, and all people can feel the innovation of fintech. Also, the threat of cybercrime can, at any time, steal someone's data to make fictitious transactions.

In China, many fintech lending actors are indicated to have carried out the Ponzi scheme. In the case of Ezubao, the lending platform is indicated to have carried out the Ponzi scheme with more than $95 \%$ of its fictional lending to lure investors with promises of yields above $14.6 \%$ per year. Ezubao also managed to collect US \$ 7.6 billion (Katada.co.id, 2018). The Ponzi scheme is a fake investment mode that pays profits to investors from other investors' money.

Other cases that occur in Indonesia, many users of online lending services through fintech peer to peer lending feel intimidated with high interest and security of personal data. Many cases of borrowers who are entangled in defaults get intimidation and even terror that triggered a suicide committed by a man in South Jakarta (cnnindonesia.com, 2019). The man committed suicide because he has the burden of being chased by moneylenders, and the man is indicated to make online loans on an illegal fintech peer to peer lending platform.

The rise of illegal peer to peer fintech platforms are obliged to know by potential investor and borrowers. As of January 2019, OJK had released 231 illegal peer-to-peer fending companies that were still illegal (OJK, 2019). This number is very far compared to the number of entities that have been legally registered as many as 78 fintech peer to peer lending entities (OJK, 2018). Moreover, among the officially registered fintech peer to peer lending entities, two entrants run their businesses with the sharia system, namely Amartha and Ammana.

Despite the shortcomings of the fintech system, it cannot be denied that the presence of fintech has an impact on the development of financial inclusion. 
22 | Muhammad Doddy, Zahrotul Millah: The Influence of Invesment Knowledge on The Interest of Students Investing in Peer to Peer Lending Shariah

Many Indonesian people have the potential to become investors for those who need funds to run a business (Haryono, 2017). A peer to peer lending system can be an option for investing.

Nevertheless, the fact is that investment interest is still quite low when compared to other countries, which is evidenced by the number of accounts registered on the IDX, only around 1 million accounts (Haryono, 2017). The percentage of Indonesians who have an investment account is only $0.59 \%$

Tabel 1 Percentage Indonesian Investor

\begin{tabular}{|lll|}
\hline & $\begin{array}{c}\text { \% Population who have } \\
\text { investment account }\end{array}$ & Adult population \\
\hline Singapore & $31.81 \%$ & 5.0 \\
\hline Malaysia & $10.85 \%$ & 23.0 \\
\hline Thailand & $4.90 \%$ & 39.4 \\
\hline Philipines & $1.17 \%$ & 63.3 \\
\hline Indonesia & $0.59 \%$ & 70.9 \\
\hline
\end{tabular}

Source : (Haryono, 2017)

One because that makes people still not interested in investing is a lack of knowledge about investment, and lack of knowledge about various investment instruments (Haryono, 2017). This causes the public to assume that investment activities only take place in the capital market so that it creates fear and is reluctant to start investing because it is considered too complicated. As for the development of investors in the field of peer to peer lending, investment is still less when compared to investors on the Indonesian stock exchange. 
Jurnal Ekonomi dan Perbankan Syariah

Vol. 7. No.2, 0ktober 2019: 20-33, ISSN (cet): 2355-1755 | ISSN (online): 2579-6437

| 23

Figure 1 characteristics of lenders in peer to peer lending

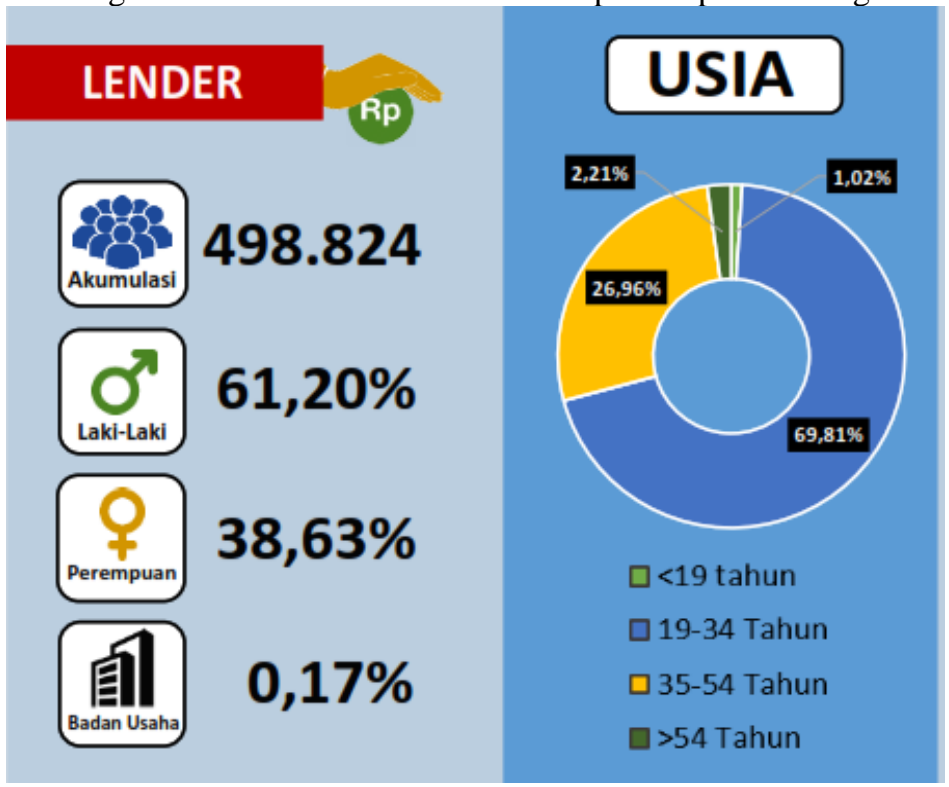

Source : OJK, 2019

Based on statistical data as of 30 June 2019, the number of investors in the peer to peer lending platform numbered 498,824 borrowers or lenders (Deputy Commissioner for Supervision of IKNB II, 2019). The most dominating age range is 19-34 years. According to Boan Sinapar, who is the VP of Business Development in Smart Credit, most $90 \%$ of its customers are employees who are under 40 years old (Aldila, 2018). Whereas in the age range of 19-34 years is the age range for students as well. However, the percentage of investors from among students is still smaller when compared to employees.

Fintech with a peer to peer lending system is an investment media that should be tried by young people like students who understand the investment or lay people in the investment world, which is low as an investment learning medium as well as an option for investing (Stephanie, 2018). Besides, ownership is flexible only in a short period, unlike stock investments. Furthermore, finally peer to peer lending investment can be made with diversification to prevent higher risk (Stephanie, 2018).

In general, fintech companies provide user-friendly services with technology that is easily accessible to the public (Haryono, 2017). The platform will present digital information that can be easily accessed by investors. Moreover, fintech companies already have a sufficient legal and regulatory basis 
24 | Muhammad Doddy, Zahrotul Millah: The Influence of Invesment Knowledge on The Interest of Students Investing in Peer to Peer Lending Shariah

in Indonesia, which is stated in POJK 77 / POJK.01 / 2016 concerning Information Technology Lending and Borrowing Services (OJK, 2017).

Other benefits from investing through peer to peer lending can start with a nominal that is not too large, only around Rp 100,000 (Haryono, 2017). Profitsharing is also varied depending on the level of risk. Another facility provided to peer to peer lending is that the community can play an active or passive role. If the community decides to play a passive role, the peer to peer lending fintech companies provides an auto investment feature so that people only need to monitor their investment portfolios regularly (Haryono, 2017).

The convenience provided by a peer to peer lending fintech companies should be able to attract students to invest and eliminate the notion that investment is a complicated thing (Stephanie, 2018). With the fintech innovation in the investment world so that investment activities can be done very quickly only through a smartphone.

Like investment activities, in general, to start investing peer to peer lending must be done with knowledge. Knowledge is beneficial for dealing with the possibilities that occur as a result of the choices and risks that will be faced will run fine (Susanto, 2012). because each investment product has a different level of risk and return. Some STEI SEBI students with a background in studying economics must already have adequate knowledge about investment when compared to other general public.

STEI SEBI students have understood investment theory because they have gotten several courses studying investment theory more deeply. As in the course of non-bank financial institutions discusses several business institutions engaged in financial services other than banking. One of the non-bank financial institutions discussed is financial institutions that conduct investment activities such as fintech peer to peer lending. Furthermore, in the capital market course, learn more details about investment products. So it can be concluded that STEI SEBI students who have received non-bank financial institution and capital market courses already know investment, including peer to peer

\section{LITERATURE REVIEW}

\subsection{Investment Interest}

Interest is a tendency or big heart desire for something (Kamus Besar Bahasa Indonesia, 2005). Of course, to arouse one's interest in something requires an excuse to become an attraction. Investment is a part of the consumption composition, which is expected to have added value in the future (Artaya, Anom, \& Artini, 2014). If concluded, the investment interest is a tendency or desire for someone's heart to invest.

The first component in private spending is consumption and savings, and then the next component is an investment (Ibrahim, 2016). So that investment decisions will be chosen by individuals when consumption and savings are well guaranteed. Investment is a fluctuating component compared to the consumption and savings components. According to the Keynesian theory of investment, the 
Jurnal Ekonomi dan Perbankan Syariah

Vol. 7. No.2, 0ktober 2019: 20-33, ISSN (cet): 2355-1755 | ISSN (online): 2579-6437

| 25

factors that generally affect investment are the interest rate, the amount of capital available, and the current economic situation (Haavelmo, 1960). However, all that can be said is the long-term factor. In Keynesian theory, there is a short-term factor that must also be considered, namely expectation or hope (Haavelmo, 1960).

According to Nadjib, Lestari, \& Jusmaliani (2008), the decision of a Muslim to invest in a particular field is based on his initiative. Not because of coercion, or vice versa, where his partners work together on his initiative. Thus, investment activities will be far from the elements of coercion, persecution, and tyrannical ((Surah An-Nisa [4]: 29, Surah Al-Baqarah [2]: 279) ".

\subsection{Knowledge of Investment}

Investors must own knowledge based on investment in order to be wise in determining the right steps in investing and avoid fraud. According to Brian Tracy in the book (Susanto, 2012), there are three pillars to achieve financial freedom; a person must have savings, insurance, and investment. It must be understood that investment, in addition to providing benefits, also contains risks, and both of these must be accepted by investors (Susanto, 2012).

According to (Susanto, 2012) three things must be understood by potential investors, namely knowledge about investment needs that are used for planned purposes; for example, the purpose is to buy a house. Next is knowledge about the risks to be faced and understand what risks will be received both micro and macro risks. Moreover, the last is knowledge about cash flow, the need for good cash flow in a certain period.

\subsection{Investment Products}

For the achievement of investment objectives, a decision is needed in determining what products will be used so that it can bring the desired results (Herlianto, 2011). This is because each investment product has different characteristics. Like the level of risk and profit. The higher the risk, the greater the benefits to be gained. Conversely, the lower the risk, the lower the profits. In addition to the level of risk and profit, each investment product has a different attractiveness. In general, investment products are divided into two types, namely investment in the real sector and the financial sector

In the fintech era, the investment world began to develop with the use of technology in every investment activity. The use of technology can make it easier for investors to monitor their portfolios. Another convenience is that fintech-based investment companies will invite other parties to become investors or funders (OJK, 2017).

\subsection{Investement Risk}


26 | Muhammad Doddy, Zahrotul Millah: The Influence of Invesment Knowledge on The Interest of Students Investing in Peer to Peer Lending Shariah

Investment risk has two types, namely, systematic risk and unsystematic risk(Artaya et al., 2014). Systematic risk is commonly referred to as market risk or general risk (general risk), which is an external risk, namely changes in market conditions such as inflation and global economic conditions. Unsystematic risk is also called specific risk (company risk) is the risk that comes from the condition of the investment issuing company. Every investment company has distinctive characteristics in managing risk.

\subsection{Profit}

Keynesian investment theory races on profits; this is because investment activities can open new jobs and increase profits from increased production so that they can create better returns (Asimakopulos, 2014). This is also in line with research conducted by Sodik \& Nuryadin (2005) investment in the form of investment can have an influence on economic growth in a positive direction. In addition to profits in the form of indirect contributions to economic growth, an investment can also provide benefits in the form of benefits for investors.

Each investment product has a different form and amount of profit. As in the real sector investment product, the form of gold investment profits is the result of sales that differ from investment products in the financial sector, which are mostly in the form of interest rates (Herlianto, 2011).

\subsection{Fintech and Peer to Peer Lending}

The immediate impact of this rapid technological development is the presence of technology that can help financial literacy, namely financial technology. This is the shifting era from traditional banking to the fintech era, an era where technologies such as peer to peer payment, cloud computing, social media, and blockchain are tools used by financial institutions to create financial products and services that many people need (Kasali, 2018).

Peer to peer lending has two types, namely commercial and noncommercial (Lenz, 2016). The striking difference between the two types is profit. Non-commercial peer to peer lending is a platform aimed at social activities without expecting a profit. Whereas commercial peer to peer lending is a business activity in which each party will expect profits.

The success of this peer to peer lending system on the market is that investors can divide their funds to allocate their investment funds in several fields or multi-investment (Widoatmojo, 2016). The owner of the investment fund can choose and consider each risk to be chosen. Peer to peer lending companies' functions as intermediaries between investment fund owners and borrowers on a platform (Bholat \& Atz, 2016). In addition to being an intermediary, peer to peer lending companies also has a function to make regulation of financing activities.

Peer to peer lending in Indonesia also accommodates people in Indonesia who want to become investors to get a return in the future (OJK, 2017). The 
Jurnal Ekonomi dan Perbankan Syariah

Vol. 7. No.2, 0ktober 2019: 20-33, ISSN (cet): 2355-1755 | ISSN (online): 2579-6437

\section{| 27}

fintech companies, especially peer to peer lending in Indonesia, are overseen by an institution called the Financial Services Authority. According to article 1 POJK No. 77 / POJK.0 / 2016 paragraph 9 Users of Information Technology Lending and Borrowing Services, in the future referred to as Users, are Lenders and Loan Recipients who use Information Technology Based Money Lending and Borrowing Services (OJK, 2016).

\section{RESEARCH METHODOLOGY}

The type of data used in this study is quantitative, mixed data with calculations from questionnaires and qualitative interviews. This study uses primary data sources. The population in this study is STEI SEBI Students, and the sample used is students who have insight into investment and know about the development of fintech. Primary data were analyzed by a simple regression analysis method and assisted with the application of SPSS ver 23.

\section{RESULTS AND DISCUSSION}

This study will explain the description of investment knowledge (X), which consists of 3 indicators, namely knowledge of the type of investment, Knowledge of Investment Risk, and knowledge of investment returns and student interest in investing on a peer to peer lending (Y) platform. To find out the level of respondents understanding of investment, a trial of respondents' knowledge of investment material and peer to peer lending was conducted, and the results were:

Table 2 Value of Investment Knowledge Test

\begin{tabular}{|c|c|c|}
\hline No & Jumlah Responden & Test Value \\
\hline 1 & 16 & 10 \\
\hline 2 & 20 & 9 \\
\hline 3 & 21 & 8 \\
\hline 4 & 18 & 7 \\
\hline 5 & 8 & 6 \\
\hline 6 & 6 & 5 \\
\hline 7 & 1 & 4 \\
\hline
\end{tabular}

Source: Processed Data, 
28 | Muhammad Doddy, Zahrotul Millah: The Influence of Invesment Knowledge on The Interest of Students Investing in Peer to Peer Lending Shariah

In this descriptive analysis will be discussed how respondents who already know the field of investment provide responses to each statement item/question given. The results of the statistical description are shown in the table below. Based on Table 3 about the detailed results from 90 samples, it is known that the average answer related to 10 items statement about investment interest $(\mathrm{Y})$ is 38.84 .

Tabel 3 Scale Statistiks

\begin{tabular}{|c|c|c|c|c|}
\hline $\mathrm{N}$ & Mean & Variance & Std. Deviation & $\mathrm{N}$ of Items \\
\hline 90 & 38.84 & 13.661 & 3.696 & 10 \\
\hline
\end{tabular}

Source: Processed Data,

The validity test in this study was assisted by SPSS ver 23 . The validity testing in this study used a significance level of 0.05 . To determine the validity of each question in the questionnaire is done by comparing the $r$ count (corrected item-total correlation) with $r$ table. If the results of the $r$ count $>r$ table, then the question item can be determined valid. The results of the validity test will be listed in the table below.

Based on table 4.3, it can be seen that all questions have $r$ count $>r$ table. To get $r$ tables, we can use the formula $(\mathrm{df}=\mathrm{N}-2)$. The number of samples in this study was 90 , so that $\mathrm{df}=90-2=88$. This study used a significance level of 0.05 , and then the $\mathrm{r}$ table was 0.17 . If seen in the table above, all questions have $r$ count $>r$ table, then all items stated above are valid.

Tabel 4 Item-Total Statistik

\begin{tabular}{|l|l|l|l|l|l|}
\hline \multirow{2}{*}{ Variabel } & $\begin{array}{c}\text { Indikato } \\
\mathrm{r}\end{array}$ & $\begin{array}{c}\text { Scale Mean if } \\
\text { Item Deleted }\end{array}$ & $\begin{array}{c}\text { Scale } \\
\text { Variance if } \\
\text { Item Deleted }\end{array}$ & $\begin{array}{c}\text { Corrected } \\
\text { Item-Total } \\
\text { Correlation }\end{array}$ & $\begin{array}{c}\text { Cronbach's } \\
\text { Alpha if } \\
\text { Item Deleted }\end{array}$ \\
\hline $\mathrm{Y}$ & $\mathrm{Y} 2$ & 34.88 & 11.929 & .377 & .758 \\
$\mathrm{Y} 2$ & 35.24 & 11.760 & .346 & .762 \\
$\mathrm{Y} 2$ & 35.00 & 11.326 & .453 & .748 \\
$\mathrm{Y} 2$ & 35.23 & 10.675 & .606 & .727 \\
$\mathrm{Y} 1$ & 35.00 & 11.236 & .476 & .745 \\
$\mathrm{Y} 1$ & 34.88 & 11.255 & .461 & .747 \\
$\mathrm{Y} 1$ & 34.88 & 12.019 & .263 & .773 \\
$\mathrm{Y} 2$ & 34.91 & 11.048 & .489 & .743 \\
& $\mathrm{Y} 2$ & 34.87 & 11.106 & .399 & .757 \\
& $\mathrm{Y} 3$ & 34.71 & 11.129 & .498 & .742 \\
\hline
\end{tabular}


Jurnal Ekonomi dan Perbankan Syariah

Vol. 7. No.2, 0ktober 2019: 20-33, ISSN (cet): 2355-1755 | ISSN (online): 2579-6437

| 29

Source: Processed Data, 2019

After all the questions are tested, the validity of the next step is that all questions must be tested for reliability. The reliability test results will be listed in the table below.

Tabel 5 Reliability Test

\begin{tabular}{|l|c|c|}
\hline & $\begin{array}{c}\text { Cronbach's } \\
\text { Alpha }\end{array}$ & Nof Items \\
\hline $\begin{array}{l}\text { Minat Mahasiswa Investasi Peer to peer } \\
\text { lending }\end{array}$ & 0.770 & 10 \\
\hline
\end{tabular}

Source: Processed Data, 2019

Based on Table 5, it can be seen that the value of the Cronbach's alpha investment interest variable is 0.770 , the value is greater than the minimum limit of Cronbach's alpha $>0.60$. This value indicates that the research questionnaire used was reliable.

From the ANOVA test or F test, the calculated $\mathrm{F}$ value is 0.040 , with a significance of 0.842 . Because the significance is far higher than 0.05 , the regression model cannot be used to predict student interest in peer to peer lending investment. The calculated F value in the study (Saputra, 2018) is 21,080, with a significance of 0,000 , which illustrates that the benefits, capital, motivation, and education variables have a significant influence on investment interest.

Tabel 6 ANOVA ${ }^{\mathrm{a}}$

\begin{tabular}{|c|c|c|c|c|c|c|}
\hline \multicolumn{2}{|c|}{ Model } & $\begin{array}{l}\text { Sum of } \\
\text { Squares }\end{array}$ & Df & $\begin{array}{l}\text { Mean } \\
\text { Square }\end{array}$ & $\mathrm{F}$ & Sig. \\
\hline \multirow[t]{3}{*}{1} & Regression & .006 & 1 & \multirow{3}{*}{$\begin{array}{l}.006 \\
.138\end{array}$} & \multirow[t]{3}{*}{.040} & \multirow[t]{3}{*}{$.842^{\mathrm{b}}$} \\
\hline & Residual & 12.153 & 88 & & & \\
\hline & Total & 12.158 & 89 & & & \\
\hline
\end{tabular}

Source: Processed Data,

a. Dependent Variable: minat

b. Predictors: (Constant), pengetahuan 
30 | Muhammad Doddy, Zahrotul Millah: The Influence of Invesment Knowledge on The Interest of Students Investing in Peer to Peer Lending Shariah

From the SPSS output model summary display, the adjusted size $\mathrm{R}^{\wedge} 2$ is -0.11 . If the adjusted $R \wedge 2$ result is negative, then the adjusted value of $R \wedge 2$ is considered to be a value of 0 . This result explains that the ability of the independent variables can be weak enough to predict the dependent variable. From this output also obtained the coefficient of determination (R-square) of 0,000 , this means that the influence of the independent variable $(X)$ investment knowledge on the dependent variable (Y) student interest in peer to peer lending investment is $0 \%$. This result means that investment knowledge does not influence to predict student interest in peer to peer lending investment.

Tabel 7 Model Summary ${ }^{b}$

\begin{tabular}{|r|r|r|r|c|}
\hline Model & $\mathrm{R}$ & R Square & $\begin{array}{c}\text { Adjusted R } \\
\text { Square }\end{array}$ & $\begin{array}{c}\text { Std. } \\
\text { Error of } \\
\text { the } \\
\text { Estimate }\end{array}$ \\
\hline 1 & $.021^{\mathrm{a}}$ & .000 & -.011 & .37162 \\
\hline
\end{tabular}

Sumber : Data dioolah, 2019

Simple regression analysis is used to test the effect of independent variables on the dependent variable, each of which $\mathrm{x}$ and $\mathrm{y}$ variables only have one variable. The independent variable $(\mathrm{X})$ in this study is investment knowledge, and the dependent variable (Y) in this study is the interest of students investing peer to peer lending. This study uses a significance level of $5 \%$ testing $(\alpha=0.05)$. The results of a simple regression analysis can be seen in the table below.

Table 8 Results of Simple Linear Regression Analysis

\begin{tabular}{|c|c|c|c|c|c|c|}
\hline & \multirow[b]{2}{*}{ Model } & \multicolumn{2}{|c|}{$\begin{array}{l}\text { Unstandardized } \\
\text { Coefficients }\end{array}$} & \multirow{2}{*}{$\begin{array}{l}\text { Standardized } \\
\text { Coefficients } \\
\text { Beta }\end{array}$} & \multirow[b]{2}{*}{$\mathrm{T}$} & \multirow[b]{2}{*}{ Sig. } \\
\hline & & B & Std. Error & & & \\
\hline \multirow[t]{2}{*}{1} & (Constant) & 3.926 & .211 & & 18.628 & .000 \\
\hline & Pengetahuan & -.052 & .260 & -.021 & -.200 & .842 \\
\hline
\end{tabular}

Sumber : Data diolah, 2019

Based on table 8 , we get the simple linear regression equation as follows. $\mathrm{Y}=$ $3,926-0.52 \mathrm{X}$

The negative correlation coefficient indicates that the correlation between the two variables is in the opposite direction. If the variable (X) 
Jurnal Ekonomi dan Perbankan Syariah

Vol. 7. No.2, 0ktober 2019: 20-33, ISSN (cet): 2355-1755 | ISSN (online): 2579-6437

\section{| 31}

investment knowledge experiences an increase in the variable (Y), it will decrease. That is, an increase in investment knowledge will result in a decrease in investment interest in peer to peer lending.

From the output, the table obtained a significance value of 0.841 . If the significance value is more significant than 0.05 , it can be concluded that the investment knowledge variable (X) does not have a significant influence on the student interest variable in investing peer to peer lending $(Y)$. The value of $t$ arithmetic obtained from the output of -0.200 , this indicates that $t$ arithmetic smaller than $\mathrm{t}$ Table of 1.66 means that the investment knowledge variable (X) has no significant adverse effect on the variable student interest in investing peer to peer lending $(\mathrm{Y})$.

Based on the results of interviews with respondents who have a negative relationship between variable $\mathrm{x}$ and variable $\mathrm{y}$, many conclusions can explain the reasons why investment knowledge does not affect peer to peer lending investment interests. The lack of knowledge of students' interest in investing in peer to peer lending is partly due to the absence of direct practice regarding peer to peer lending investment itself so that students only get theories without direct practice. That causes students only to understand it as a theory. Besides, limitations in understanding practically result in anxiety to start investing peer to peer lending.

The second thing that makes investment knowledge does not influence peer to peer lending investment interest is that the selection of the type of investment they are interested in is indeed not in the type of peer to peer lending investment, for example in the real sector investment. The third thing that makes there is no relationship in this research is that some students still think that they do not need investment because their needs are currently limited to the needs of students. Alternatively, it can be said that investment awareness in students is still reasonably low.

\section{CONCLUSION}

Based on the results of the analysis and discussion of research results the influence of investment knowledge on student interest in investing peer to peer lending, it can be concluded that based on the T-test results of -0.200 , indicating that the independent variable namely student knowledge $(\mathrm{X})$ has a negative influence on student interest in investing peer to peer lending (Y). Also, if it is seen from the significance value of 0.842, it shows that the influence between investment knowledge does not have a significant effect on students' interest in investing peer to peer lending. So it can be concluded that investment knowledge does not have a significant effect on student interest in investing peer to peer lending.

Qualitative data support quantitative data calculation resu lts through interviews of 10 respondents. The results of the qualitative data are some respondents who already have excellent investment knowledge. However, low 
32 | Muhammad Doddy, Zahrotul Millah: The Influence of Invesment Knowledge on The Interest of Students Investing in Peer to Peer Lending Shariah

interest in investing peer to peer lending is caused by the lack of socialization of the peer to peer lending investment system so that they only understand theoretically. The next motive is the level of doubt that is still reasonably high due to not understanding it in practice, although the peer to peer lending investment system is very appropriate for use by young people or those who are just trying to invest.

\section{REFERENCES}

Aldila, N. (2018). Kredit Pintar Gencarkan Literasi ke Daerah. Bisnis Indonesia, p.

https://www.idx.co.id/StaticData/NewsAndAnnouncement/ANNOUNCE MENTSTOCK/From_EREP/201808/38a36ba910_c79cc39ad3.pdf

Artaya, M., Anom, I. B. P., \& Artini, G. L. S. (2014). Pengaruh Faktor Ekonomi Makro, RIsiko Investassi dan Kinerja Keuangan Terhadap Returt Saham Perusahaan di Bursa Efek Indonesia (BEI). Ekonomi Dan Bisnis Udayana, 12, 689-701.

Asimakopulos, A. (2014). The Determination of Investment in Keynes 's Model. Canadian Economics Association, 4(3), 382-388. https://doi.org/10.2307/133783

Deputi Komisioner Pengawas IKNB II. (2019). Perkembangan Fintech Lending (Pendanaan Gotong Royong On-Line).

Haavelmo, T. (1960). A Study in the Theory of Investment. The Universiy of Chicago Press. https://doi.org/6013057

Haryono, B. (2017). “ Meningkatkan Minat Investasi Melalui Peer-to-Peer Lending " Singapore Malaysia Thailand Philippines Indonesia \% population who have an investment account Adult population ( mio ) Return on Investment ( ROI ) dari Investasi di Amerika dan Indonesia, 2016-2018.

Herlianto, D. (2011). Keputusan Preferensi Investasi Aset Riil dan Aset Finansial dengan Model Minimax Regret, 15(1), 96-104.

Ibrahim, A. H. (2016). Ekonomi Makro. Jakarta: Kencana.

Kamus Besar Bahasa Indonesia ( $3^{\text {rd }}$ ed). (2005). Jakarta: PT Penerbit dan Percetakan BALAI PUSTAKA.

Nadjib, M., Lestari, E., \& Jusmaliani. (2008). Investasi Syari'ah Implementasi Konsep pada Kenyataan Empirik. (Jusmaliani, Ed.). Yogyakarta: Kreasi Wacana.

OJK. (2017). Kajian Perlindungan Konsumen Sektor Jasa Keuangan: Perlindungan Konsumen Pada Fintech.

OJK. (2019). Daftar 231 Entitas FIntech Peer-to-Peer Lending Ilegal yang 
Jurnal Ekonomi dan Perbankan Syariah

Vol. 7. No.2, 0ktober 2019: 20-33, ISSN (cet): 2355-1755 | ISSN (online): 2579-6437

\section{| 33}

Dihentikan Satgas Waspada Investasi 13 Februari 2019.

OJK Duga Korban Bunuh Diri Pinjam Uang dari Fintech Ilegal. (n.d.). Cnnindonesia.Com, $\mathrm{p}$.

2019.

https://www.cnnindonesia.com/ekonomi/20190213200418-78-

369043/ojk-duga-korban-bunuh-diri-pinjam-uang-dari-fintech-ilegal

Saputra, D. (2018). Pengaruh Manfaat, Modal , Motivasi dan Edukasi Terhadap Minat Dalam Berinvestasi di Pasar Modal, 5(2), 178-190.

Setyowati, D. (2018). Langkah OJK Memagari Sisi Negatif Fintech Pembiayaan. Katadata.Co.Id. Retrieved from https://katadata.co.id/berita/2018/09/09/langkah-ojk-memagari-sisinegatif-fintech-pembiayaan

Sodik, J., \& Nuryadin, D. (2005). Investasi dan Pertumbuhan Ekonomi Regional (Studi Kasus Pada 26 Propinsi di Indonesia Pra dan Pasca Otonomi), 157170.

Stephanie, K. (2018). Investasi Peer to Peer Lending Ternyata Cocok Untuk Anak Muda, Lho. Ini Alasannya! Retrieved from https://koinworks.com/blog/investasi-p2p-lending-untuk-anak-muda/

Sulistiawati, R. (2012). Pengaruh Investasi terhadap Pertumbuhan Ekonomi dan Penyerapan Tenaga Kerja Serta Kesejahteraan Masyarakat di Provinsi di Indonesia, 3(1), 29-50.

Susanto, H. (2012). Cerdas Memilih Investasi. Jakarta: PT Elex Media Komputindo.

Suwiknyo, D. (2017). Karyawan (juga) Bisa Kaya. Jakarta: PT Elex Media Komputindo.

Zeng, X., Liu, L., Leung, S., Du, J., Wang, X., \& Li, T. (2017). A decision support model for investment on P2P lending platform. PLoS ONE, 12(9), 1-18. https://doi.org/10.1371/journal.pone.0184242 